\title{
STABLE WATER-ISOTOPE STUDIES FOR DECIPHERING THE RECENT STRUCTURE AND HOLOCENE EVOLUTION OF THE EAST ANTARCTIC ICE-SHEET MARGIN NEAR $12^{\circ} \mathrm{E}$ (Abstract)
}

\author{
by \\ W.-D. Hermichen and G. Strauch \\ (Central Institute of Isotope and Radiation Research, Academy of Sciences of the GDR, \\ Permoserstraße 15, 705-Leipzig, German Democratic Republic) \\ and \\ R. Vaikmäe \\ (Institute of Geology, Academy of Sciences of the Estonian SSR, \\ 7 Estonia Avenue, 200101 Tallinn, U.S.S.R.)
}

\section{ABSTRACT}

Since 1978 scientists from the German Democratic Republic, in collaboration with members of Soviet Antarctic Expeditions, have been studying the isotopic composition of ice and snow, as well as the trapped gas content of glacier ice from northern Queen Maud Land near $12^{\circ} \mathrm{E}$, in order to decipher recent structures and Holocene evolution of this part of the margin of the East Antarctic ice sheet.

Along a $180 \mathrm{~km}$ north-south profile three large bodies could be distinguished: (1) Novolazarevskaya Ice Shelf ( $100 \mathrm{~km}$ wide, $\$ 700 \mathrm{~m}$ thick); (2) the ice cover ( $30 \mathrm{~km}$ wide, $\$ 300 \mathrm{~m}$ thick) of the Skaly Instituta Geologii Arktiki nunataks ["Skaly IGA"], with a scarp to the Schirmacher oasis; and (3) a firn glacier ( $50 \mathrm{~km}$ wide, c. $1000 \mathrm{~m}$ thick), filling the depression between "Skaly IGA" and the Wohlthat massif.

The ice-flow conditions of the surface layer are known. On the basis of isotope profiles from Soviet drilling sites on the ice shelf ( $447 \mathrm{~m}$ core) and on the firn glacier ( $809 \mathrm{~m}$ core), from the scarp and slope of the inland ice to the south of the Schirmacher oasis (ablation zone), and from numerous pits through the surface layer, a preliminary stratigraphic model has been developed.

On the basis of recent flow conditions, the basal layer of Novolazarevskaya Ice Shelf and that of the inland ice of the "Skaly IGA" region were identified as relics of late Pleistocene ice cover by their mean deuterium content of -390 and $-330 \%$ respectively. The old ice is covered by Holocene layers of regional origin ( $8 \mathrm{D}=-230$ to $-150 \%)$; in the ice shelf there are also layers derived from the interior of Antarctica ( $\delta \mathrm{D}=-350$ to $-280 \%)$.

The isotope profile of the firn glacier (range of $\delta^{18} \mathrm{O}$ variations -32.3 to $-18.1 \%$, identifiable annual layers of about $20 \mathrm{~cm}$ of ice to a depth of $500 \mathrm{~m}$ ) represents a unique record of the last 7-8 ka for this region. It is also supported by measurements of the total air content trapped in ice samples $\left(V=107-127 \mathrm{~cm}^{3} / \mathrm{kg}\right)$ taken from the $809 \mathrm{~m}$ core. Details will be published elsewhere.

More information is expected to be provided by isotope studies of extended blue-ice fields and ice-cored moraines. 